\title{
Supernumerary Fascicle of Abductor digiti minimi Muscle and Compression of Ulnar Nerve and Ulnar Artery: A Case Report
}

\author{
Fascículo Supernumerario del Músculo Abductor del dedo Mínimo \\ y Compresión del Nervio y Arteria Ulnares: Reporte de Caso \\ "Thejodhar, P.; "*Sampath, K. Madhyastha; "Bhagath Kumar, Potu; "Sreedhar, V.; \\ **** Binod, K. T.; *Chakravarthy, M.; ${ }^{* * * *}$ Ramana, V. \& ****:Satish, N.
}

THEJODHAR, P.; SAMPATH, K. M.; BHAGATH, K. P.; SREEDHAR, V.; BINOD, K. T.; CHAKRAVARTHY, M.; RAMANA, V. \& SATISH, N. Supernumerary fascicle of Abductor digiti minimi muscle and compression of ulnar nerve and ulnar artery. A case report. Int. J. Morphol., 25(4):763-765, 2007.

SUMMARY: The supernumerary fascicles of abductor digiti minimi muscle have been implicated in vascular and nerve compression. During routine dissection of an old male cadaver we observed an anomalous muscle was found to take it's origin from the antebrachial fascia and flexor retinaculum, traversed ulnar canal (Guyon's) superficial to ulnar vessels and nerves to reach the proximal part of abductor digiti minimi. The anomaly is one of a kind. Its course through Guyon's canal could be a cause for Guyon's canal syndrome. It was innervated by the ulnar nerve.

KEY WORDS: Ulnar nerve; Ulnar artery; Supernumerary fascicle; Abductor digiti minimi; Guyon's canal.

\section{INTRODUCTION}

The anomalies of the hypothenar muscles can be classified as absences, duplications, fusions with neighboring muscles and variations of their origin and insertion. Among them, there are also accessory or supernumerary fascicles of abductor digiti minimi. In addition to being infrequent (Wood, 1868; Le Double, 1897; Reiman et al., 1944; Furnas, 1965), these anomalies are of clinical interest in view of their relation to vessels and nerves. It is accepted that $2.9 \%$ of cases of ulnar nerve compression are due to the existence of an aberrant muscle (Shea \& McClain, 1969). The majority of the reported cases represent surgical findings in patients with compression of ulnar nerve. This of course means that in many of these patients no anatomical details of the fascicle responsible for the compression were available. In this report we describe the anatomical finding of an anomalous muscle could be a potential cause for ulnar nerve compression. Guyon's canal syndrome also called as the ulnar tunnel syndrome, caused due to compression of the ulnar nerve as it passes through the ulnar canal (Guyon's) is a well recognized entity (Cem Bozkurt, 2005). Guyon's canal is a fibro-osseous tunnel in the anteromedial portion of the wrist, about 4- 4.5 $\mathrm{cm}$ in length and contains the ulnar nerve and artery. Its roof is formed by the palmar carpal ligament, (antebrachial fascia), and the palmaris brevis muscle, the floor is formed by the hypothenar muscles and the flexor retinaculum. On the radial side, the tunnel is limited by the junction of the roof and the flexor retinaculum and thenar muscles. On the ulnar aspect, the tunnel demarcated by the roof merging with the, fascia covering the hypothenar muscles.

\section{CASE REPORT}

In the Department of Anatomy, Kasturba Medical College, Manipal, during routine dissection, in a 52 year old male cadaver an anomalous muscle was noticed in the

\footnotetext{
* Department of Anatomy, Kasturba Medical College, Manipal, Karnataka - 576104, India.

** Department of Anatomy, Kasturba Medical College, Mangalore, Karnataka - 575004, India.

*** Department of Anatomy, SMIMS, Gangtok, Sikkim, India.

**** Department of Anatomy, MMMC, Manipal, Karnataka - 576104, India.
} 
right forearm. The proximal fibers of this muscle were seen taking their origin from the antebrachial fascia and the distal fibers from the flexor retinaculum. Traced distally both fibers were observed to join the proximal portion of abductor digiti minimi muscle. The length of this muscle was $5.2 \mathrm{~cm}$; and its breadth was $1.2 \mathrm{~cm}$. Both, the ulnar nerve and artery were seen to take a course deep to this muscle (Fig. 1). The innervation arose from the ulnar nerve as a delicate twig which branched off at the point where the nerve was crossed superficially by the muscle.

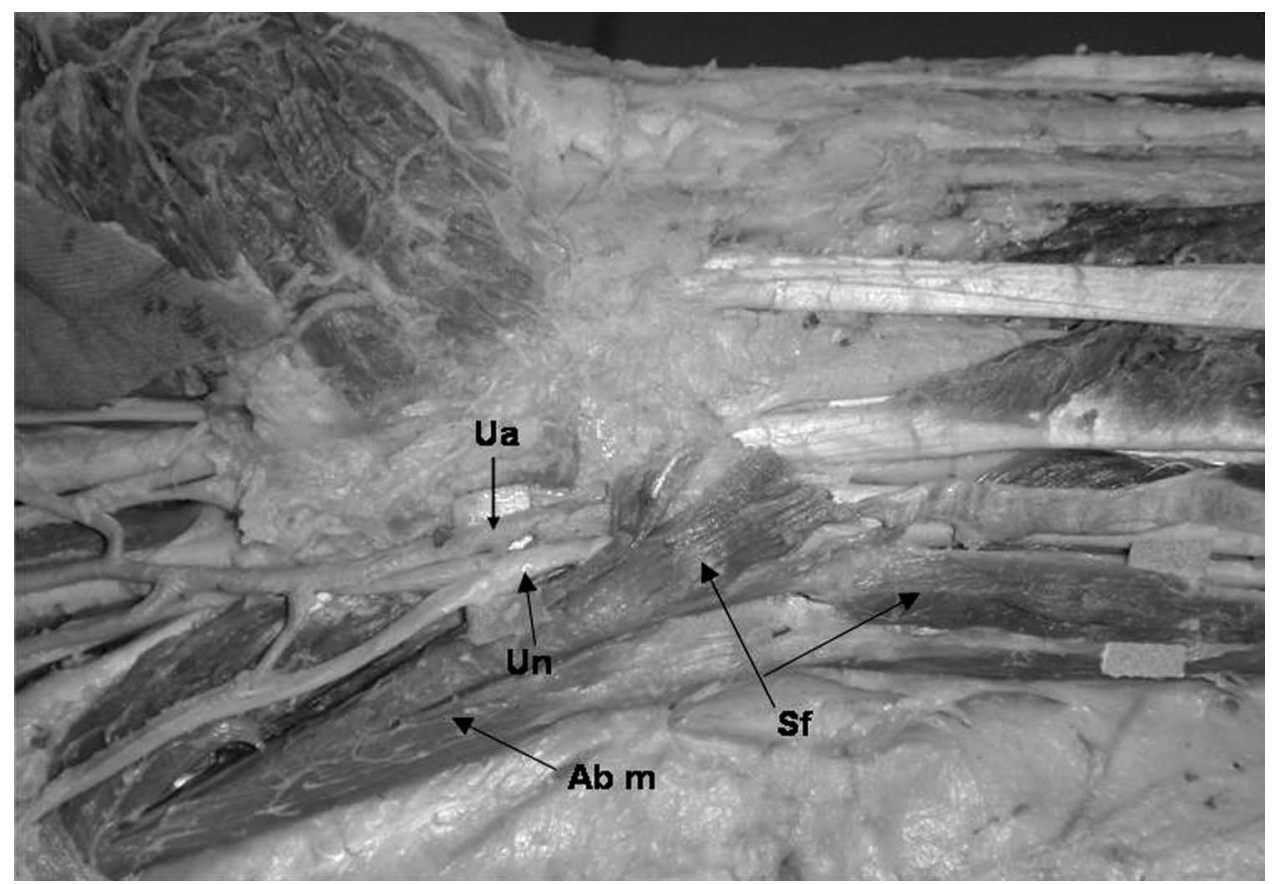

Fig.1. Supernumerary fascicle of the abductor digiti minimi crossing the ulnar nerve and vessels. SfSupernumerary fascicle of Abductor digiti minimi muscle. Un- ulnar nerve; Ua - ulnar artery; Ab m - Abductor digiti minimi muscle

\section{DISCUSSION}

We consider the occurrence of such supernumerary anomalous muscles as an unusual persistence of an undifferentiated group of mesenchymal cells. Since, the aforesaid muscle is taking origin partly from the roof (antebrachial fascia) and partly from the floor (flexor retinaculum) of ulnar canal. And therefore every time it contracts the tunnel will be squeezed, thereby the likelihood of compression of the contents of the ulnar canal is very high. Especially, more during movements of the fingers like in grasping etc, and can lead to sensory, motor and vascular abnormalities in territory of the ulnar nerve and artery. Compression of the ulnar nerve in the ulnar canal, though not very common, has been reported and studied (Cem Bozkurt, 2005). The compression can occur at 3 zones proximodistally (Michael \& Richard, 1985). In zone-1 the ulnar nerve is yet to bifurcate into its sensory and motor branches, whereas zones 2 and 3 are distal where the ulnar nerve has divided into motor and sensory branches. Symptoms of compression will correspond to the site of compression (Posner, 2000). Such observations necessitate the clinician to consider this as one of the differential diagnosis for conditions with symptoms of neurovascular compression in the hand. The diagnosis of carpal tunnel syndrome cannot be resorted to in all cases of tingling and numbness of the hand. Thorough examination and investigation will be necessary to clinch any diagnosis.

Such anomalous muscles may also be associated with ulnar artery thrombosis (Pribyl \& Moneim, 1994). A history of repetitive blunt trauma along the ulnar border of the hand, and presenting with a mass or ischemia in the hand may be suggestive of ulnar artery thrombosis. 
THEJODHAR, P.; SAMPATH, K. M.; BHAGATH, K. P.; SREEDHAR, V.; BINOD, K. T.; CHAKRAVARTHY, M.; RAMANA, V. \& SATISH, N. Supernumerary fascicle of Abductor digiti minimi muscle and compression of ulnar nerve and artery. A case report. Int. J. Morphol., 25(4):763-765, 2007.

ACKNOWLEDGMENTS: We thank Dr. Narga Nair, Head of the Department of Anatomy, Kasturba Medical College,
Manipal for her support and Mr. Ganesh Kini, Office secretary, Department of Anatomy for his help.

THEJODHAR, P.; SAMPATH, K. M.; BHAGATH, K. P.; SREEDHAR, V.; BINOD, K. T.; CHAKRAVARTHY, M.; RAMANA, V. \& SATISH, N. Fascículo supernumerario del músculo abductor del dedo mínimo y compresión del nervio y arteria ulnares. Reporte de caso. Int. J. Morphol., 25(4):763-765, 2007.

RESUMEN: Los fascículos supernumerarios del músculo abductor del dedo mínimo han sido implicados en la compresión neurovascular. Durante una disección de rutina de un cadáver masculino adulto, se observó un músculo anómalo que se originaba en la fascia antebraquial y en el retináculo flexor, atravesaba el canal ulnar, superficial a los vasos y nervio ulnares para llegar a la parte proximal del músculo abductor del dedo mínimo. La anomalía es única en su tipo. Su curso a través del canal ulnar puede causar el síndrome del canal ulnar. El músculo estaba inervado por el nervio ulnar. nal ulnar.

PALABRAS CLAVE: Nervio ulnar; Arteria ulnar; Fascículo supernumerario; Músculo abductor del dedo mínimo; Ca-

\section{REFERENCES}

Cem Bozkurt, M.; Suleyman Murat, T. \& Levent Ozcakar. Anatomical variations as potential risk factors for ulnar tunnel syndrome: A cadaveric study. Clin. Anat., 18:274-80, 2005.

Furnas, D. W. Muscle - tendon variations in the flexor compartment of the wrist. Plastic and Reconstructive Surgery, 36:320-4, 1965 .

Le Double, A. F. Traité des variation du systeme musculare de home et de leur signification au point de vue de anthropologie zoologique. Paris, Schleicher Freres, 1897. Vol. 2. pp. 170-8.

Michael, S. \& Richard, H. The anatomy of the distal ulnar tunnel. Clinical Orthopaedics and Related Research, 196:239-47, 1985.

Posner, M.A. Compressive neuropathies of the ulnar nerve at the elbow and wrist. Instr. Course Lect., 49:305-17, 2000 .

Pribyl, C.\& Moneim, M. S. Anomalous hand muscle found in the Guyon's canal at exploration for ulnar artery thrombosis: A Case Report. Clin. Orthop. Relat. Res., 306:120-3, 1994.

Reimann, A. F. \& Daseler, E. H. \& Anson, B. J. The palmaris longus muscle and tendon. A study of 1600 extremities. Anat. Record, 89:495-505, 1944.

Shea, J. D. \& McClain, E. J. Ulnar nerve compression syndromes at and below the wrist. J. of bone and Joint Surgery, 51A:1095-102, 1969.
Wood, J. Variations in human mycology observed during the winter season of 1867-68 at king's college, London. In Variations in Human Myology, Vol 17. Proceedings of the Royal Society of London, 16: 483-525, 1868.

\author{
Correspondence to: \\ Dr. Thejodhar P. \\ Assistant Professor in Anatomy, \\ Kasturba Medical College \\ Manipal, Karnataka \\ 576104. \\ INDIA
}

Phone: 091-09845135335.

Email: thejodhar@gmail.com

Received: 19-03-2007

Accepted: 14-05-2007 
